\title{
Bacteriological assessment of water from an Eastern Amazon river: challenges in ensuring basic sanitary coverage in riverside communities
}

\author{
Avaliação bacteriológica da água de um rio da Amazônia Oriental: desafios para garantir a \\ cobertura sanitária básica em comunidades ribeirinhas \\ Evaluación bacteriológica del agua de un río en la Amazonía Oriental: desafíos para garantizar la \\ cobertura sanitaria básica en las comunidades ribereñas
}

Received: 08/20/2021 | Reviewed: 08/29/2021 | Accept: 09/03/2021 | Published: 09/05/2021

\author{
Vinicius Pacheco da Silva \\ ORCID: https://orcid.org/0000-0001-8117-320X \\ Evandro Chagas Institute, Brazil \\ E-mail: viniciuspchc@icloud.com \\ Elizandra Baía Carneiro \\ ORCID: https://orcid.org/0000-0003-4137-7771 \\ Escola Superior da Amazônia, Brazil \\ E-mail: elizandra.baia@hotmail.com \\ Laura Marcela Teotônio Magalhães \\ ORCID: https://orcid.org/0000-0002-0820-971X \\ Escola Superior da Amazônia, Brazil \\ E-mail: lauramagalhaes9875@gmail.com \\ Adria Caroliny Vieira Mendonça \\ ORCID: https://orcid.org/0000-0002-8988-4898 \\ Escola Superior da Amazônia, Brazil \\ E-mail: adria-modas@hotmail.com \\ Milena Machado de Matos \\ ORCID: https://orcid.org/0000-0003-3276-4139 \\ Escola Superior da Amazônia, Brazil \\ E-mail: milena.matos.med@gmail.com \\ Ana Kelly Carvalho Gomes \\ ORCID: https://orcid.org/0000-0002-0291-2201 \\ Escola Superior da Amazônia, Brazil \\ E-mail: annagomes792@gmail.com \\ Diogo de Matos Botelho \\ ORCID: https://orcid.org/0000-0002-9387-9725 \\ Escola Superior da Amazônia, Brazil \\ E-mail: deogo31@gmail.com \\ Andrei de Souza Simões \\ ORCID: https://orcid.org/0000-0001-8915-4476 \\ Escola Superior da Amazônia, Brazil \\ E-mail: andreisimoes@gmail.com
}

\begin{abstract}
This study aimed to analyze the water quality of a river in the Eastern Amazon and relate the results obtained with the lack of basic sanitation in the region. Two samples were collected from strategic points of the river and were submitted to the collimetry technique with multiple tubes to calculate the most probable number (MPN) of thermotolerant coliforms present in the water. The samples were then seeded on CLED and Hektoen agar and analyzed in a mass spectrophotometer for final identification of microorganisms. A high number of thermotolerant coliforms was detected, in addition to bacteria of clinical importance, such as Pseudomonas aeruginosa, Shigella spp. and Cronobacter sakazakii. The lack of basic sanitation in the community surrounding the river is the main cause for the significant number of thermotolerant coliforms, demonstrated by the discrepancy in the MPN between samples 1 and 2 . The difficulties in guaranteeing basic sanitation in the Amazon are highlighted and the need to implement public policies and carry out health surveillance studies in these populations is reinforced.
\end{abstract}

Keywords: Basic sanitation; Riverside communities; Water microbiology.

\section{Resumo}

Este estudo teve como objetivo analisar a qualidade da água de um rio na Amazônia Oriental e relacionar os resultados obtidos com a falta de saneamento básico na região. Duas amostras foram coletadas de pontos estratégicos do rio e 
foram submetidas à técnica colimetria com tubos múltiplos para o cálculo do número mais provável (NMP) de coliformes termotolerantes presentes na água. As amostras foram semeadas em ágar CLED e Hektoen e analisadas em espectrofotômetro de massa para identificação final de microrganismos. Foi detectado um alto número de coliformes termotolerantes, além de bactérias de importância clínica, como Pseudomonas aeruginosa, Shigella spp. e Cronobacter sakazakii. A falta de saneamento básico na comunidade do entorno do rio é a principal causa do número expressivo de coliformes termotolerantes, demonstrada pela discrepância do NMP entre as amostras 1 e 2. Destaca-se as dificuldades na garantia de saneamento básico na Amazônia e reforça-se a necessidade da implementação de políticas públicas e da realização de estudos de vigilância em saúde nessas populações.

Palavras-chave: Saneamento básico; Comunidades ribeirinhas; Microbiologia da água.

\section{Resumen}

Este estudio tuvo como objetivo analizar la calidad del agua de un río en la Amazonia Oriental y relacionar los resultados obtenidos con la falta de saneamiento básico en la región. Se recolectaron dos muestras de puntos estratégicos del río y se sometieron a la técnica de colimetría con múltiples tubos para calcular el número más probable (NMP) de coliformes termotolerantes presentes en el agua. Las muestras se sembraron en agar CLED y Hektoen y se analizaron en un espectrofotómetro de masa para la identificación final de los microorganismos. Se detectó un elevado número de coliformes termotolerantes, además de bacterias clínicamente importantes como Pseudomonas aeruginosa, Shigella spp. y Cronobacter sakazakii. La falta de saneamiento básico en la comunidad aledaña al río es la principal causa del expresivo número de coliformes termotolerantes, demostrado por la discrepancia del NMP entre las muestras 1 y 2 . Se resaltan las dificultades para garantizar el saneamiento básico en la Amazonía y se refuerza la necesidad de implementar políticas públicas y realizar estudios de vigilancia de la salud en estas poblaciones.

Palabras clave: Saneamiento básico; Comunidades ribereñas; Microbiología del agua.

\section{Introduction}

Water is an indispensable resource for the maintenance of life in the biosphere, as it is responsible for the terrestrial balance, participates in the composition of complex structures of living beings, acts in the osmotic transport of substances, allows the existence of chemical reactions, not to mention of being a natural habitat for countless species, from large marine animals to microscopic bacteria (Martins; Da Luz; Adamatti, 2017).

As stated by the Brazilian Ministry of Environment, water pollution is one of the main threats to human health and the environment. In addition, more than 100 million Brazilians do not have access to sewage treatment. The Ministry has also reported several recurrent environmental problems in the north of Brazil, including the lack of basic sanitation, pollution and inadequate use of water resources, along with the indiscriminate use of groundwater (Brasil, 2020; Gorayeb; Lombardo; Pereira, 2009).

A health survey carried out in the northern state of Amazonas identified a rate of $32.7 \%$ of diarrhea in riverside communities, the most prevalent symptom reported by the interviewed persons. Other symptoms such as gastritis (28.6\%), heartburn (22.4\%) and vomiting (16.3\%) were also reported (Gama et al., 2018). The main hypothesis for such high numbers is the ingestion of food and water contaminated with microorganisms that infect the gastrointestinal tract.

Official Brazilian statistics concluded that $55.6 \%$ of households in the Amazon region do not receive proper or any sewage treatment (IBGE, 2018). The lack of basic sanitation directly influences the spread of pathogenic bacteria. About $90 \%$ of the microorganisms that cause water-borne diseases are of fecal origin (Moretto, 2018). Riverside communities are at greater risk of developing gastrointestinal diseases when compared to developed urban populations and its resources.

In developing countries, $80 \%$ of diseases are derived from the unsatisfactory water, leading to the death of 3 million people per year worldwide. It is estimated that half of the entire population in these countries is suffering from one or more of the six major diseases associated with water supply and sanitation (diarrhea, ascariasis, dracunculiasis, schistosomiasis, ancylostomiasis and trachoma). (Conceição \& Rodrigues, 2017; PAHO, 2001). In the state of Pará, 162,203 cases of acute diarrhoeal disease (ADD) were registered in 2018, ranking as the second state with the highest number of ADD cases in the Northern region of Brazil (Brasil, 2019).

The quality of drinking water is a determining factor for the emergence of gastrointestinal infections that can lead to 
complications such as severe diarrhea and possible death. Furthermore, cases of acute diarrhea are frequent in the Eastern Amazon, as a direct consequence of the deficiency of health infrastructure and surveillance (Sánchez-Gutierrez et al., 2020). Therefore, it is important to develop and maintain a quality control surveillance in water resources, mostly among Amazonian populations.

Thus, this study aimed to analyze the water quality in an Eastern Amazon river, through a bacteriological assessment, and to discuss how the results are influenced by the poor sanitary coverage in the region, since the literature still lacks of further elucidation about the quality and potability of water in small villages and riverside communities in the Amazon, a neglected territory that has been suffering from excessive water pollution and deficits of social and environmental assistance.

\section{Methodology}

\subsection{Type of Study}

This is an experimental study that used the colimetry assay, a technique that detects the presence of thermotolerant coliforms and quantifies these microorganisms based on the color change of the reagents. All methodological support, from the creation of maps to water collection and the laboratorial analysis, was based on and adapted from the Manual of Water Analysis from the National Health Foundation / Ministry of Health (FUNASA, 2013) and the handbook for Methodology of Scientific Research (Pereira et al., 2018).

\subsection{Study Area}

The Eastern Amazon comprises the Brazilian states of Pará, Maranhão, Amapá, Tocantins and Mato Grosso (Brasil, 2021). The object of study is Genipaúba river (Figure 1), located in the homonymous island that is part of the city of Abaetetuba, state of Pará. The municipality of Abaetetuba is made of seventy-two islands and sixteen urban neighborhoods. The city has an estimated population of 153,380 inhabitants. The rivers, streams and creeks are part of the municipality's islands, adding more 50,000 inhabitants (IBGE, 2017). The distance between Abaetetuba's city center and Genipaúba river is approximately 3.36 km (Figure 2). A small community of about 85 families and 312 people live just by the river (Da Silva, 2018).

Figure 1. Genipaúba river.

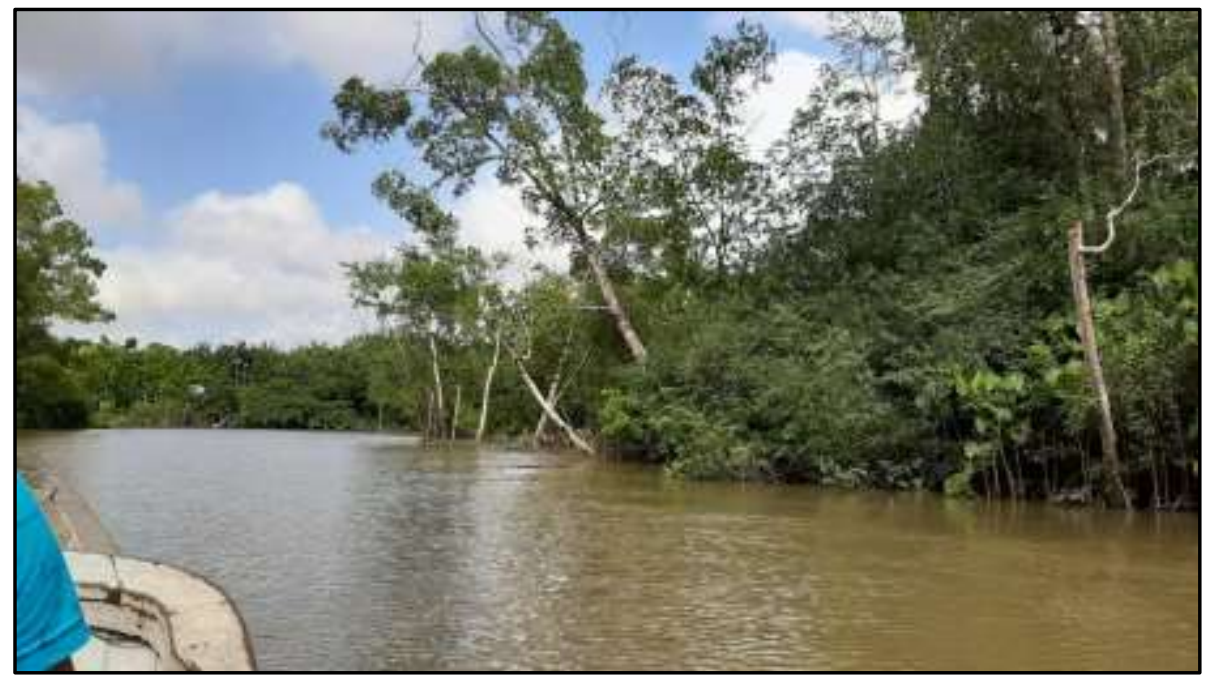

Source: Authors (2020). 
Figure 2. Distance between Abaetetuba's port, in the city center (red pin) and Genipaúba river (yellow pin).



Source: Google Earth (2021).

\subsection{Sample Collection}

To investigate if the riverside community takes part in Genipaúba's bacteriological imbalance, two strategical spots for water collection were established: spot 1 was set at the end of the river, approximately 50 meters past the last house, meanwhile, spot 2 was set right at the beginning of the river, around 80 meters before the first house (Figure 3).

Figure 3. Distance between each collection spot along Genipaúba.



Source: Google Earth (2021).

For the sample collection, two sterile bottles with a capacity of 500 milliliters $(\mathrm{ml})$ were used for the predetermined spots. After the collection, the bottles were sealed, and the samples were carefully placed into an isothermal box with ice so that no losses occurred during the transport. The amount of ice was enough to keep the samples refrigerated between 3 degrees Celsius $\left({ }^{\circ} \mathrm{C}\right)$ to $8{ }^{\circ} \mathrm{C}$ until the arrival at the laboratory. Samples 1 and 2 were obtained and analyzed in September 2020. 


\subsection{Bacteriological Analysis}

The first method used to verify the presence and to quantify coliform bacteria is the multi-tube colimetry technique, which allows to determine the most probable number (MPN) of coliforms per $100 \mathrm{ml}$ of water based on the color change of the tubes, from green to yellow. Seeding was carried out in 30 Durham tubes (15 for each water sample collected) containing bright green broth, divided into 3 rows of 5 tubes each.

The first row was diluted in 1:1 concentration ( $3 \mathrm{ml}$ of bright green broth and $3 \mathrm{ml}$ of the sample), the second and third rows were diluted in 1:10 (0.3 ml of sample) and 1:100 (0.03 ml of sample) respectively. All 30 tubes were incubated at $36{ }^{\circ} \mathrm{C}$ for 48 hours. The calculation of MPN is based on in-house protocols for colimetry of the laboratory where this research was conducted.

To support the analysis, samples 1 and 2 were seeded in two solid mediums: Cystine Lactose Electrolyte Deficient (CLED) and Hektoen agar. The first is used as a medium to differentiate lactose fermenting and non-fermenting species; while the purpose of the second is to isolate Gram-negative enteric pathogens, as specified by the fabricant. The Petri dishes were incubated at $36^{\circ} \mathrm{C}$ for 48 hours. After 48 hours, the agar plates were subject to a mass spectrophotometer as a final confirmation method to identify the most prevalent species.

\section{Results}

The calculation of MPN is based on the combination of color change of the broth in each row, from an intense dark green shade (considered negative) to a pale green or yellowish shade (considered positive). The conversion of the macroscopic results into numbers was based on the in-house guide for reading the MPN of coliforms per $100 \mathrm{ml}$. The authors identified a combination 3-4-4 of positive tubes in sample 1 (Figure 4) and 1-5-2 in sample 2 (Figure 5), therefore the most probable number of coliforms for samples 1 and 2 is 36 and 17 respectively.

Figure 4. Sample 1: combination of positive tubes in the rows 1 (a), 2 (b) and 3 (c).

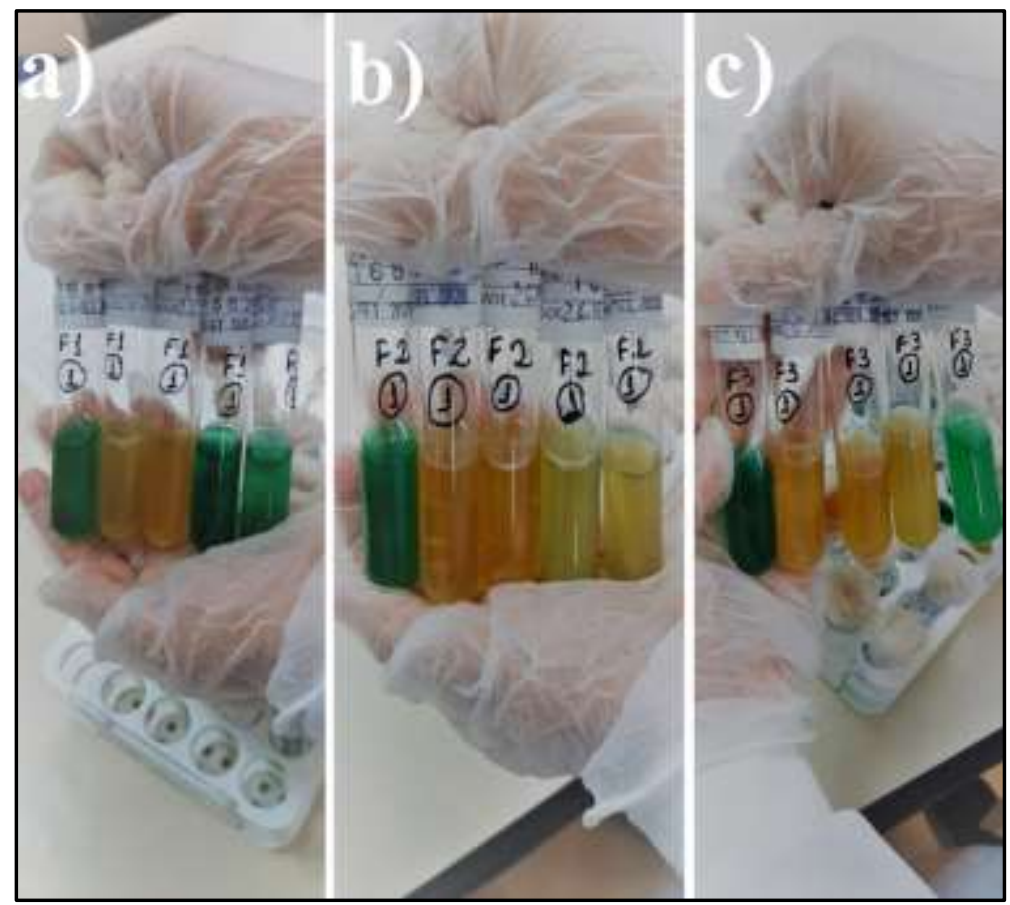

Source: Authors (2020). 
Figure 5. Sample 2: combination of positive tubes in the rows 1 (a), 2 (b) and 3 (c).

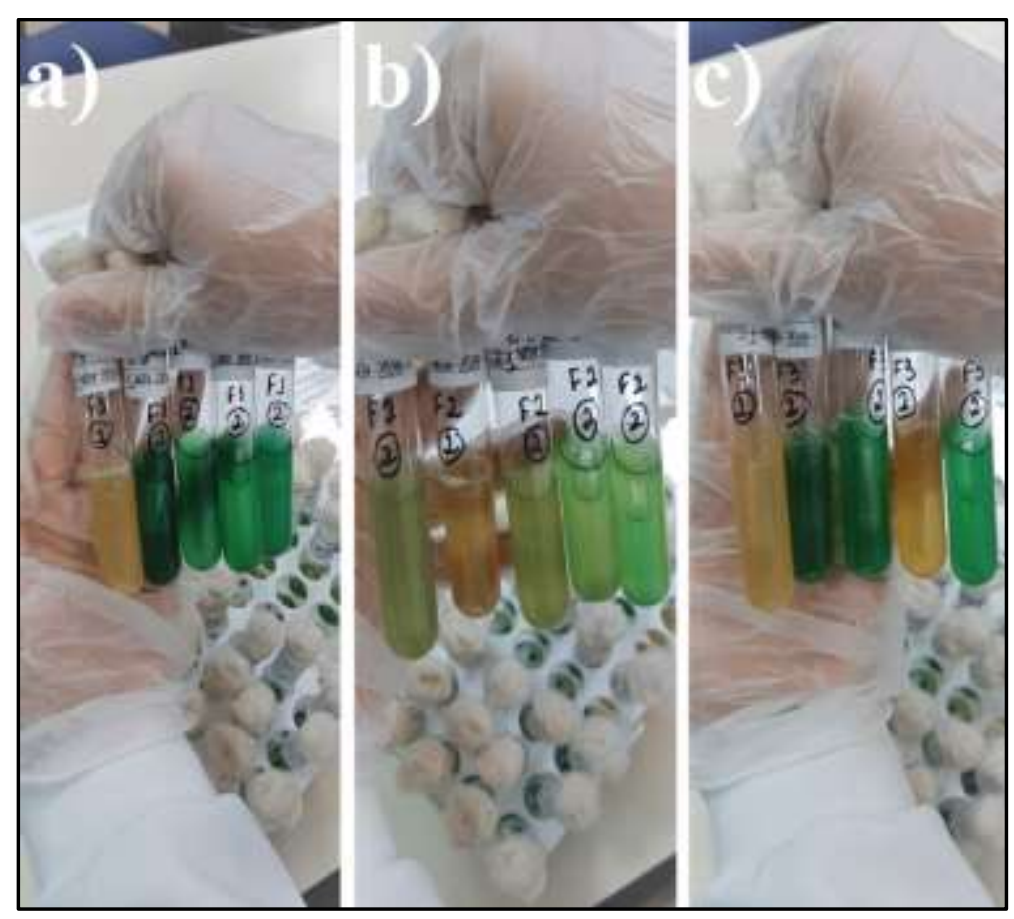

Source: Authors (2020).

Moreover, it was detected on CLED agar plates, purple colonies that suggest the presence of Cronobacter spp., in addition to the change of colors, from light blue to yellow, which shows the presence of lactase-positive microorganisms, typically Escherichia coli, according to the fabricant's manual (Figure 6).

Figure 6. Lactase-positive bacteria turned the medium from cyan to yellow, and Cronobacter spp. (purple colonies) on CLED agar.

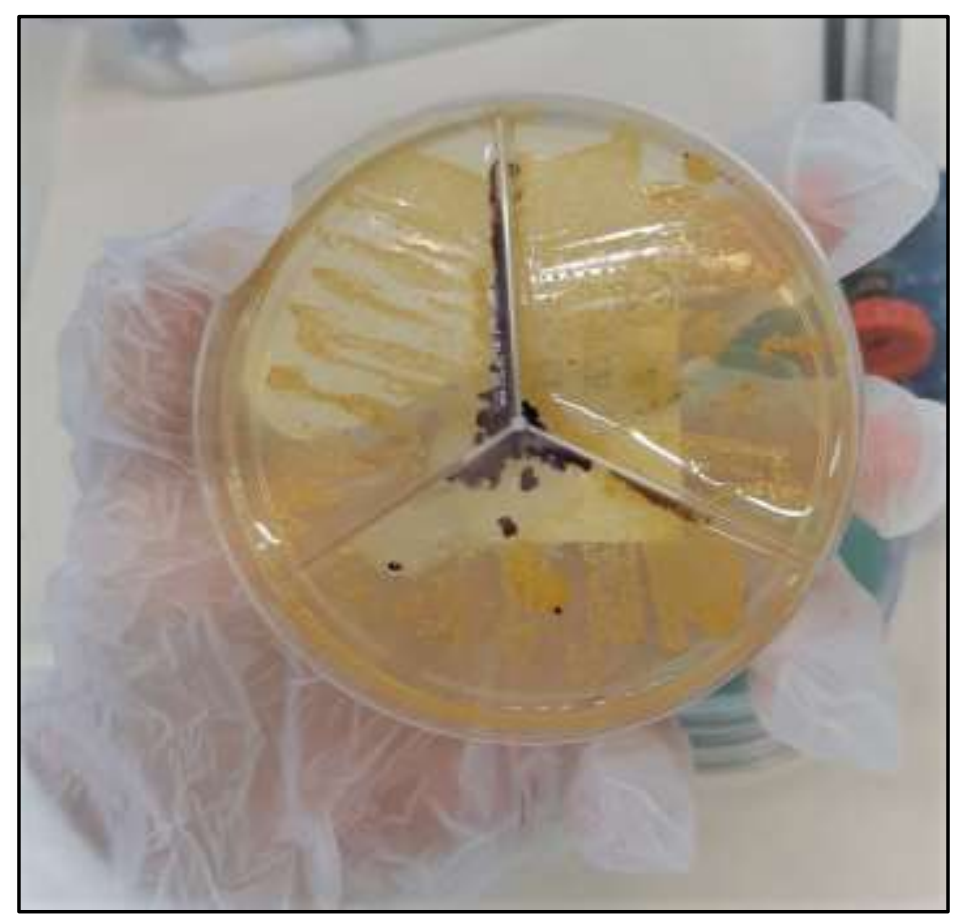

Source: Authors (2020). 
On Hektoen agar plates, it was observed growth of bright orange colonies, suggestive of $E$. coli and small green colonies, that indicates the presence of Shigella spp. (Figure 7), according to the fabricant's manual.

Figure 7. Bright orange colonies (E. coli) and small green colonies (Shigella spp.) on Hektoen agar.

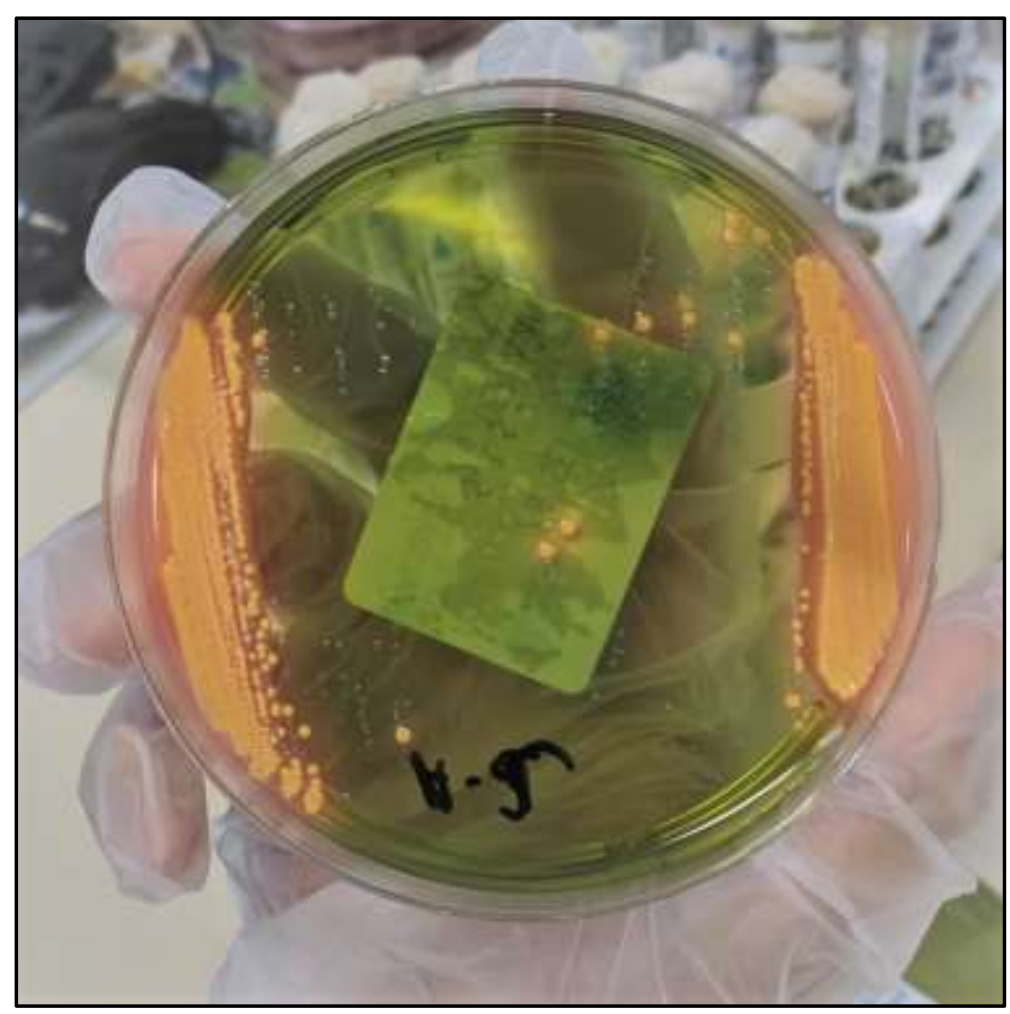

Source: Authors (2020).

Finally, the mass spectrophotometer identified the species present in each agar plate. In CLED agar, Escherichia coli and Cronobacter sakazakii were detected (99\% of probability). In Hektoen agar, the most prevalent species were E. coli followed by Shigella spp. (94\% of probability). Colonies of Pseudomonas aeruginosa and Klebsiella pneumoniae (97\% and $89 \%$ of probability respectively) were also detected by the spectrophotometer.

\section{Discussion}

The scant infrastructure in riverside communities results in the disposal of biological waste into the river course, which contributes to the increase of pathogenic microorganisms. In this study, we found out that the water analyzed contains a large number of thermotolerant coliforms, along with bacteria of public health importance, which indicates that the riverine community of Genipaúba takes part in the results detected.

The noticeable difference both in quantity of coliforms and in the diversity of species found in samples 1 (collected at the end of the river) and 2 (collected at the beginning of the river) suggests that the Genipaúba riverside community performs the disposal of faecal waste in the water. In addition, thermotolerant coliforms constitute the intestinal microbiota of humans and warm-blooded animals, therefore, they have become markers of the water potability index, as the presence of coliforms in water indicates contamination caused by the discharge of sewage waste (Souza et al, 1983).

The bacteriological diversity found in this study is in line with the microbiological profile evaluated by Ben-Eledo et al. (2017) in a creek in Nigeria. The authors isolated a considerable number of both pathogenic and enteropathogenic species of bacteria, and concluded that anthropogenic interference, such as the discharge of sewage water directly into the creek, are 
responsible for the results.

The most probable number of coliforms present in the analysis by Porcy et al. (2020) is relatively smaller than those identified in this study. This may be due to the sanitation and sewage disposal conditions, which are deficient in the outskirts of the city of Macapá, where Porcy and collaborators conducted the research, although, it is not even similar to the total inexistence of basic sanitation in some isolated riverside communities in the Amazon.

The inadequate sanitary system in these communities is the main cause for the significant increase in the number of thermotolerant coliforms in the analyzed samples, as the waste dumped into the water directly interferes in the river's micro ecosystem, facilitating the emergence of enterobacterial diseases, therefore, impacting the quality of life of the surrounding population (Neu; Dos Santos; Meyer, 2016). Severe complications from diarrhea can arise and lead to death, especially in children aged 0-5 years old, who can be classified as a risk group (WHO, 2017). In addition, acute diarrheal disease is recurrent in the Brazilian Amazon, which directly implies urgency in the implementation and development of basic sanitation and sanitary education by the population (Brasil, 2019).

According to the last census carried out by the Brazilian Institute of Geography and Statistics (IBGE, 2010), 15\% of rural households in Brazil do not have a bathroom. In the Amazon region, the rate of households without a bathroom rises to $19 \%, 10 \%$ of which is only in the state of Pará. Furthermore, only $8 \%$ of houses located in rural regions of Pará have septic tanks. In some riverside communities, the most common practice is to use the river itself as a place for dumping sewage.

Another factor that can interfere in the concentration of thermotolerant coliforms is the high temperature over the year, characteristic of the Amazon's equatorial climate, combined with the absence of well-defined seasons, condition that provides the ideal temperature for the continuous reproduction of microorganisms (Da Silva, 2006).

The sample size of this research is limited, therefore, future studies that can cover long periods of the year and take into account climatic, pluviometric and sociodemographic changes, along with pathogen-specific features, like antibiotic resistance, are important to understand the water microbiological profile in the long-term and in specific conditions.

\section{Conclusion}

This study identified the presence of bacteria of medical importance in both samples. In addition, the analysis detected a high quantity of coliforms, which exceeded the potability limits. Sample 1 showed a great discrepancy in its MPN when compared to sample 2. Thus, it is understood that the residents of the area contribute to the bacteriological imbalance in the river, as a consequence of the poor basic sanitation coverage in the region. The community nearby the river is widely exposed to infections, considering that most activities carried out by the locals involve direct consumption of water and other domestic and leisure activities. Undeniably, government interventions that include riverside communities in infrastructure and basic sanitation plans is a must.

Furthermore, the authors highlight the importance of developing future studies focused on monitoring the concentrations of these microorganisms in water resources over the months, assess the possible resistance to antibiotics, and to conduct an updated health survey in the Eastern Amazon, because infections caused by enterobacteria are frequent in this region, and there is a necessity of obtaining up-to-date statistics concerning coliform-associated complications. In addition, it is necessary to facilitate the access to health in riverside populations across the Amazon, because they are not included within the health coverage area in the same proportion as urban centers. 


\section{References}

Ben-Eledo, V. N., Kigigha, L. T., Izah, S. C., \& Eledo, B. O. (2017). Bacteriological quality assessment of water from Epie creek, Niger Delta region of Nigeria. International Journal of Ecotoxicology and Ecobiology, 2(3), 102-108.

Brasil. Ministério do Desenvolvimento Regional. Superintendência do Desenvolvimento da Amazônia. (2021). Legislação da Amazônia. https://www.gov.br/sudam/pt-br/acesso-a-informacoes/institucional/legislacao-da-amazonia.

Brasil. Ministério do Meio Ambiente. (2020). Qualidade da Água. https://www.gov.br/mma/pt-br/assuntos/agendaambientalurbana/qualidade-da-agua.

Brasil. Ministério da Saúde. (2019). Dados de doenças diarreicas agudas (DDA) https://www.saude.gov.br/saude-de-a-z/doencas-diarreicas-agudas/43216-dados

Conceição, F. S., \& Rodrigues, Z. M. R. (2017). Geografia da saúde: contexto dos agravos relacionados à água na bacia hidrográfica do rio boa hora, município de urbano santos, MA. Hygeia: Revista Brasileira de Geografia Médica e da Saúde, 13(26).

Da Silva, J. C. (2018). Educação do Campo na Interface com Projeto Político Pedagógico da EMEIF 04 de Março na comunidade Quilombola do Rio Genipaúba/ Abaetetuba-PA (Master's Dissertation, Universidade Federal do Pará).

Da Silva, D. F. (2006). Utilização de indicadores biológicos na avaliação da qualidade da água da Baía do Guajará e do Rio Guamá (Belém-Pará) (Master's Dissertation, Universidade Federal do Pará).

FUNASA. Fundação Nacional de Saúde. (2013). Manual Prático de Análise de Água. Ministério da Saúde.

Gama, A. S. M., Fernandes, T. G., Parente, R. C. P., \& Secoli, S. R. (2018). Inquérito de saúde em comunidades ribeirinhas do Amazonas, Brasil. Cadernos de Saúde Pública, 34, e00002817.

Gorayeb, A., Lombardo, M. A., \& Pereira, L. C. C. (2009). Condições Ambientais em Áreas Urbanas da Bacia Hidrográfica do Rio Caeté-Amazônia OrientalBrasil. Revista de Gestão Costeira Integrada-Journal of Integrated Coastal Zone Management, 9(2), 59-70.

IBGE. Instituto Brasileiro de Geografia e Estatística. (2017). Abaetetuba. https://cidades.ibge.gov.br/brasil/pa/Abaetetuba.

IBGE. Instituto Brasileiro de Geografia e Estatística. (2010). Censo Demográfico 2010. http://www.sidra.ibge.gov.br/bda/tabela/listabl.asp?c=1378\&z=cd\&o=7.

Martins, V. B., Luz, R., \& Adamatti, D. F. (2017). Educando e conscientizando crianças a respeito do uso da água potável através de jogos. Scientia Plena, 13(4).

Moretto, V. T. (2018). Avaliação microbiológica da água e o perfil de resistência antimicrobiana em enterobactérias de coleções hídricas de salvador e área rural da Bahia (Doctoral Dissertation, Instituto Gonçalo Moniz).

Neu, V., dos Santos, M. A. S., \& Meyer, L. F. F. (2016). Banheiro ecológico ribeirinho: saneamento descentralizado para comunidades de várzea na Amazônia. Revista Em Extensão, 15(1), 28-44.

PAHO. Pan American Health Organization. (2001). Água e Saúde. https://www.paho.org/bra/index.php?option=com_docman\&view=download\&alias=203agua-e-saude-3\&category_slug=saude-e-ambiente-707\&Itemid=965.

Pereira, A. S., Shitsuka, D. M., Parreira, F. J., Shitsuka, R. (2018). Metodologia da Pesquisa Científica. Universidade Federal de Santa Maria.

Porcy, C., da Silva Costa, T., Monteiro, V. S., Nogueira, J. N., \& de Oliveira Menezes, R. A. (2020). Avaliação microbiológica da água de consumo de casas localizadas em área alagada em um município do estado Amapá. Revista Eletrônica Acervo Saúde, 12(4), e2938-e2938.

Sánchez-Gutiérrez, R., Mena-Rivera, L., Sanchez-Murillo, R., Fonseca-Sánchez, A., \& Madrigal-Solís, H. (2020). Hydrogeochemical baseline in a humanaltered landscape of the central Pacific coast of Costa Rica. Environmental Geochemistry and Health, 42(9), 2685-2701.

Souza, L. C., Iaria, S. T., Paim, G. V., \& Lopes, C. A. M. (1983). Bactérias coliformes totais e coliformes de origem fecal em águas usadas na dessedentação de animais. Revista de Saúde Pública, 17, 112-122.

WHO. World Health Organization. (2017). Diarrhoeal disease. https://www.who.int/en/news-room/fact-sheets/detail/diarrhoeal-disease. 